Tropical Journal of Pharmaceutical Research June 2019; 18 (6): 1219-1225

ISSN: 1596-5996 (print); 1596-9827 (electronic)

(1) Pharmacotherapy Group, Faculty of Pharmacy, University of Benin, Benin City, 300001 Nigeria.

\title{
Thymoquinone enhances sperm DNA integrity in nicotine- induced infertile male rats
}

\author{
Farah Dayana Rosli ${ }^{1}$, Noor Hashida Hashim ${ }^{2 \star}$, Yusmin Mohd Yusuf ${ }^{3}$, Khairul \\ Osman ${ }^{4}$, Siti Fatimah Ibrahim $^{5}$, Nurul Kabir ${ }^{6}$ \\ ${ }^{1}$ Institute of Graduate Studies, ${ }^{2}$ Biology Division, Center for Foundation Studies in Science, ${ }^{3}$ Centre for Research in \\ Biotechnology for Agriculture, University of Malaya, 50603, ${ }^{4}$ Faculty of Allied Health Sciences, National University of Malaysia, \\ 50586, ${ }^{5}$ Faculty of Medicine, National University of Malaysia, 56000, ${ }^{6}$ Institute of Biological Sciences, Faculty of Science, \\ University of Malaya, 50603, Kuala Lumpur, Malaysia
}

*For correspondence: Email: nhhpasum@um.edu.my; Tel: +60-3-79674629

Sent for review: 21 December 2018

Revised accepted: 22 May 2019

\begin{abstract}
Purpose: To assess the effects of thymoquinone (TQ) on the integrity of sperm DNA in nicotineinduced sperm impairment in rats.

Methods: Adult male Sprague Dawley rats were randomized into four equal groups: control group received normal saline orally for 60 days; nicotine group was subcutaneously injected with $5 \mathrm{mg} / \mathrm{kg} /$ day nicotine for 30 days and then given normal saline for the next 30 days; TQ group was given normal saline for 30 days followed by TQ at $5 \mathrm{mg} / \mathrm{kg} /$ day for 30 days; and nicotine-TQ group received $5 \mathrm{mg} / \mathrm{kg}$ of nicotine for 30 days and $5 \mathrm{mg} / \mathrm{kg}$ of TQ for another 30 days. Sperm DNA breakages were evaluated using Comet assay. The expression levels of protamine 1 (PT1) and transition nuclear protein 2 (Tnp2) genes which are essential for the proper compaction of the sperm DNA were analyzed by quantitative polymerase chain reaction ( $q P C R$ ).

Results: Thymoquinone significantly decreased DNA fragmentation in the sperm of nicotine-treated rats. However, there was no change in PT1 gene expression. Tnp2 was downregulated in the nicotine group and slightly upregulated in nicotine-TQ group $(p<0.05)$.

Conclusion: The results demonstrate the potential benefits of $T Q$ in improving sperm DNA quality of nicotine-induced male infertility.
\end{abstract}

Keywords: Thymoquinone, Infertility, Nicotine, Sperm, DNA integrity, Protamine 1, Transition nuclear protein 2

\begin{abstract}
This is an Open Access article that uses a fund-ing model which does not charge readers or their institutions for access and distributed under the terms of the Creative Commons Attribution License (http://creativecommons.org/licenses/by/4.0) and the Budapest Open Access Initiative (http://www.budapestopenaccessinitiative.org/read), which permit unrestricted use, distribution, and reproduction in any medium, provided the original work is properly credited.

Tropical Journal of Pharmaceutical Research is indexed by Science Citation Index (SciSearch), Scopus, International Pharmaceutical Abstract, Chemical Abstracts, Embase, Index Copernicus, EBSCO, African Index Medicus, JournalSeek, Journal Citation Reports/Science Edition, Directory of Open Access Journals (DOAJ), African Journal Online, Bioline International, Open-J-Gate and Pharmacy Abstracts
\end{abstract}

\section{INTRODUCTION}

Drugs and chemicals may adversely affect the male reproductive system. Smoking exerts injurious effects on sperm count, kinetic parameters, morphology and DNA integrity [1]. The adverse effects of cigarette smoking on fertility could be attributed to the content of cigarettes which includes several toxic chemicals, mutagens and carcinogens. Nicotine represents $90 \%$ of the total alkaloids in cigarettes [2] and mimics most of the deleterious effects of cigarette smoking [3]. A study by Mosadegh et al determined that nicotine caused 
negative impacts by damaging DNA through apoptosis activation [4]. Increased levels of reactive oxygen species (ROS) by nicotine could also induce cellular oxidative injury that results in DNA breakage. Sperm with damaged DNA loses its ability to fertilize oocyte as sperm DNA integrity is an important factor for embryo development and offspring production [5].

DNA damage may also be a result of abnormal chromatin packaging during chromatin remodeling. The sperm chromatin is extremely compact and organized in a specific manner to provide a safe and secure transfer of paternal DNA [6]. During spermiogenesis, histones are replaced by transition nuclear proteins (Tnp). They are then replaced with protamines [7]. Disturbance of this could expose DNA to fragmentation and compromise fertility.

Medicinal herbs or plants have already been used in the treatment of various diseases. Among medicinal plants, Nigella sativa (NS) is a therapeutically-promising herb known for its pharmacological benefits. The benefits are linked to the main constituent of its volatile oil, the thymoquinone (TQ) [8]. The therapeutic potentials of Thymoquinone encompassed various areas, such as anti-bacterial activities and anxiety modulatory $[9,10]$. In the reproductive functions, TQ significantly improved semen quality and reproductive characteristics [11].

However, the effects of TQ on DNA integrity and genes responsible for chromatin packaging in the sperm cells of a nicotine-induced infertility model has not been studied so far. Therefore, the aim of the present study was to investigate the potential ameliorative role of TQ on infertilityinduced sperm damage in rats.

\section{EXPERIMENTAL}

\section{Animals}

Male Sprague-Dawley rats (7 - 9 weeks), weighing $200-250 \mathrm{~g}$ were obtained from the University of Malaya Medical Centre (UMMC), University of Malaya. Prior to treatment, rats were acclimatized to the experimental conditions in the animal house for a week. The rats were placed in separate polypropylene cages. The animals were maintained at room temperature under standard conditions of 12:12 $\mathrm{h}$ light and dark cycles. Chow pellets and water were given ad libitum daily. The experiments were conducted in accordance with the guidelines provided by the Institute of Graduate Studies and the Institutional Animal Care and Use Committee
(IACUC) of University of Malaya \{approval no. PASUM/30/12/2015/FDR(R)\}, conforming to the guidelines by National Research Council, Guide for the Care and Use of Laboratory Animals [12].

\section{Experimental design}

Thirty-two rats were randomly divided into 4 groups ( $n=8$ per group): (1) Control group, force-fed with normal saline, per oral (p.o.) for 60 days; (2) nicotine group, subcutaneously (s.c.) injected with $5 \mathrm{mg} / \mathrm{kg}$ of nicotine for 30 days, followed by normal saline (p.o.) for 30 days; (3) TQ group, force-fed with normal saline (p.o.) for 30 days, followed by TQ at $5 \mathrm{mg} / \mathrm{kg} /$ day (p.o) for the next 30 days; (4) nicotine-TQ group, injected with $5 \mathrm{mg} / \mathrm{kg} / \mathrm{day}$ of nicotine (s.c.) for 30 days, followed by force-feeding of TQ at $5 \mathrm{mg} / \mathrm{kg} / \mathrm{day}$ for 30 days. Thymoquinone ( $\geq 98 \%$ pure) was purchased from Sigma-Aldrich (St. Louis, Missouri) while nicotine (L-nicotine, 99+\% pure,) was purchased from Acros Organics (New Jersey, USA). All rats were euthanized on day 61 via ketamine-xylazine overdose (i.p.).

\section{Sample collection}

Upon euthanization, the cauda epididymis was excised from the rat testis, cut open and placed in a tube containing pre-warmed $1 \mathrm{~mL}$ phosphate buffered saline (PBS). The tube was placed in an incubator with $5 \% \mathrm{CO}_{2}, 37^{\circ} \mathrm{C}$ for $30 \mathrm{~min}$. Testes were decapsulated and cut into $50-100 \mathrm{mg}$ pieces. For gene expression analysis, testes were placed in $1 \mathrm{~mL}$ Trizol and snapped-frozen in liquid nitrogen before storage in $-80^{\circ} \mathrm{C}$.

\section{Quantitative assessment of DNA damage (Comet assay)}

The integrity of sperm DNA was assessed by performing the Comet assay with some modifications [13]. Frosted slides (StatLab Medical Product Inc., Texas) were covered with $200 \mu \mathrm{L}$ of $1 \%(\mathrm{w} / \mathrm{v})$ normal melting agar (NMA) and coverslips were placed promptly to allow it to solidify at $4{ }^{\circ} \mathrm{C}$ for $10 \mathrm{~min}$. Following this, $100 \mu \mathrm{L}$ of sperm sample $\left(1 \times 10^{5}\right.$ sperm per $\left.\mathrm{mL}\right)$ was added to $100 \mu \mathrm{L}$ of $0.5 \%(\mathrm{w} / \mathrm{v})$ low melting agarose (LMA) and $50 \mu \mathrm{L}$ of the suspension was pipetted onto the pre-coated NMA on the frosted slides. Fresh coverslips were placed and left at $4^{\circ} \mathrm{C}$ for $10 \mathrm{~min}$. A second layer of $1 \%$ LMA was pipetted and allowed to set. Following coverslips removal, the slides were placed into the first lysis buffer, at $4{ }^{\circ} \mathrm{C}$ for $1 \mathrm{~h}$, then immersed in a second lysis buffer at $37^{\circ} \mathrm{C}$ overnight.

After the lysis process, the slides were washed thrice with distilled water for 20 min to clear out 
residual lysis buffer from the gels. The slides were then settled for $20 \mathrm{~min}$ in a horizontal electrophoresis tank (Sub-Cell Model 192 cell Horizontal Electrophoresis System, Bio?Rad, Hercules, CA, USA) containing fresh electrophoresis buffer. Electrophoresis was conducted at $25 \mathrm{~V}$ and $300 \mathrm{~mA}$ for $20 \mathrm{~min}$ in room temperature. The slides were then transferred in three change of neutralizing buffer for $20 \mathrm{~min}$ each. After neutralization, slides were left to air dry and stained with Sybr Green solution before coverslips were placed for image analysis. The fluorescent-labeled DNA was visualized using inverted a fluorescent microscope (Axiovert 200M, Carl Zeiss, Germany) at x200 magnification and captured using AxioCam MRm camera (Carl Zeiss, Germany).

Comet Assay Software Project (CASP) lab Version 1.2.3b1 (Free Software Foundation Inc., Boston, MA, USA) was used to analyze the comet images. Hundred comet images were randomly analyzed per slide and DNA damage profile (tail length (TL), tail moment (TM), olive tail moment (OTM), and \% tail DNA) was computed.

\section{RNA analysis}

Trizol reagent (Invitrogen; Thermo Fisher Scientific, Inc., Waltham, MA, USA) was used to isolate total RNA from frozen rat testes according to the manufacturer's instructions. Essentially, the tissue was homogenized in Trizol $(1 \mathrm{~mL}$ of Trizol per $50-100 \mathrm{mg}$ of tissue) and incubated for $5 \mathrm{~min}$ at room temperature. An additional isolation step to remove insoluble materials from the homogenate was performed by centrifugation at $12000 \mathrm{x} \mathrm{g}$ for $10 \mathrm{~min}$ at $4^{\circ} \mathrm{C}$. The supernatant was carefully removed and placed in a new tube and mixed vigorously for 15 seconds following the addition of $200 \mu \mathrm{L}$ of chloroform. The sample was incubated for 2 to $3 \mathrm{~min}$ at room temperature and centrifuged at $12000 \times \mathrm{g}, 4^{\circ} \mathrm{C}$ for $15 \mathrm{~min}$.

The aqueous phase was transferred to a new tube and $500 \mu$ of isopropyl alcohol was added before centrifugation at $12000 \times \mathrm{g}, 4^{\circ} \mathrm{C}$ for 10 min. The RNA pellet was washed with $75 \%$ ethanol and centrifuged again at $7500 \times \mathrm{g}$ for 5 min at $4^{\circ} \mathrm{C}$. The RNA pellet was then completely dissolved in $100 \mathrm{uL}$ diethyl carbopyronate-treated water by incubating at $55-60{ }^{\circ} \mathrm{C}$ for $10 \mathrm{~min}$. The concentration, purity and integrity of the RNA were determined by NanoDrop-1000 spectrophotometer (Thermo Scientific, Washington, USA) at $260 / 280 \mathrm{~nm}$ and by electrophoresis on a $1 \%$ agarose gel, stained with GelStain (Transgen Biotech, Beijing, China).

\section{Gene expression analysis by real-time PCR}

cDNA was prepared from RNA by reverse transcription using the QuantiNova Reverse Transcription kit (Qiagen $\mathrm{GmbH}$, Hilden, Germany) according to manufacturer's protocol by utilizing $2 \mu \mathrm{g}$ total RNA in a final volume of 20 $\mu \mathrm{L}$. The obtained cDNA was stored at $-20^{\circ} \mathrm{C}$ until analysis. The gene expression analysis of $P T 1$ and Tnp2 genes were carried out using the QuantStudio 12K Flex Real-Time PCR System (Applied Biosystems, Foster City, CA, USA). Custom designed primers and probes as listed in Table 1 were synthesized by Integrated DNA Technologies. Primers were used at $250 \mathrm{nM}$ and probes at $250 \mathrm{nM}$ in a $20 \mu \mathrm{L}$ reaction containing PrimeTime Gene Expression Master Mix (Integrated DNA Technologies, Coralville, IA, USA).

The thermal cycling conditions were set at initial denaturation of $3 \mathrm{~min}$ at $95^{\circ} \mathrm{C}$ followed by 40 cycles of $95{ }^{\circ} \mathrm{C}$ for $5 \mathrm{sec}$ and primer annealing/extension temperature at $60^{\circ} \mathrm{C}$ for 30 sec. Amplification reactions were prepared in triplicate and no-template control was included. The relative expression levels of the target genes were determined by normalization to reference genes, Beta-actin (Actb) and Glyceraldehyde-3phosphate dehydrogenase (GAPDH). Normalized expression level of the samples was calculated using the geometric mean of two reference gene quantities and factoring in the primer efficiency. The data was processed using qBase+ Version 3.0 (Biogazelle, Zwijnaarde, Belgium) for statistical analysis. Utilizing the "Stat Wizard" function, significant differences of expression between the groups were analyzed by one-way ANOVA test.

\section{Statistical analysis}

The data were processed by analysis of variance (ANOVA) followed Duncan post-hoc test. Significant level was set at $p<0.05$. Data analysis was conducted with the aid of SPSS 23.0 software, except for the gene expression experiment.

\section{RESULTS}

\section{DNA damage}

The DNA damage caused by nicotine was evidenced by the increase in the DNA damage profile such as TL, TM, OTM and \% tail DNA compared to the control and TQ group $(p<0.05$; Table 2). DNA damage was reduced in the nicotine-TQ group compared to the nicotine group in all parameters. 
Table 1: Sequence information for primers and probes used

\begin{tabular}{|c|c|c|c|}
\hline $\begin{array}{c}\text { Gene and accession } \\
\text { nos. }\end{array}$ & Oligo & Sequences (5'-3') & $\begin{array}{l}\text { Amplicon size } \\
\text { (bp) }\end{array}$ \\
\hline $\begin{array}{l}\text { PT1 } \\
\text { NM_001002850.1 }\end{array}$ & $\begin{array}{l}\text { PT1 Forward } \\
\text { PT1 Reverse } \\
\text { PT1 Probe }\end{array}$ & $\begin{array}{l}\text { TGGCCAGATACCGATGCTG } \\
\text { CCTAAAGGTGTATGAGCGGC } \\
\text { CGAAGATGTCGCAGACGGAGGA }\end{array}$ & 140 \\
\hline $\begin{array}{l}\text { Tnp2 } \\
\text { NM_017057.2 }\end{array}$ & $\begin{array}{l}\text { Tnp2 Forward } \\
\text { Tnp2 Reverse } \\
\text { Tnp2 Probe }\end{array}$ & $\begin{array}{l}\text { GGAGAAGAGGAGGAGGAGGA } \\
\text { ATTGGTGTGACTTTGAGGCC } \\
\text { ATGGACACCAAGATGCAGAGCCTT }\end{array}$ & 127 \\
\hline $\begin{array}{l}\text { Actb } \\
\text { NM_031144.2 }\end{array}$ & $\begin{array}{l}\text { Actb Forward } \\
\text { Actb Reverse } \\
\text { Actb Probe }\end{array}$ & $\begin{array}{l}\text { TCTTCCAGCCTTCCTTCCTG } \\
\text { CACACAGAGTACTTGCGCTC } \\
\text { AGGAGATTACTGCCCTGGCTCCTA }\end{array}$ & 238 \\
\hline $\begin{array}{l}\text { GAPDH } \\
\text { NM_017008.4 }\end{array}$ & $\begin{array}{l}\text { GAPDH Forward } \\
\text { GAPDH Reverse } \\
\text { GAPDH Probe }\end{array}$ & $\begin{array}{l}\text { GAGACAGCCGCATCTTCTTG } \\
\text { TGACTGTGCCGTTGAACTTG } \\
\text { AGATGGTGAAGGTCGGTGTGAACG }\end{array}$ & 224 \\
\hline
\end{tabular}

Table 2: Sperm DNA damage of rats treated with nicotine and TQ

\begin{tabular}{llccc}
\hline Group & $\begin{array}{l}\text { Tail length } \\
\text { (arbitrary } \\
\text { unit) } \\
\text { (mean } \pm \text { SE) }\end{array}$ & $\begin{array}{c}\text { Tail moment } \\
\text { (arbitrary } \\
\text { unit) } \\
\text { (mean } \pm \text { SE) }\end{array}$ & $\begin{array}{c}\text { Olive tail } \\
\text { moment } \\
\text { (arbitrary } \\
\text { unit) } \\
\text { (mean } \pm \text { SE) }\end{array}$ & $\begin{array}{c}\text { Tail DNA \% } \\
\text { (mean } \pm \\
\text { SE) }\end{array}$ \\
\hline $\begin{array}{l}\text { Control } \\
\text { Nicotine }\end{array}$ & $18.98 \pm 0.28^{\mathrm{a}}$ & $1.45 \pm 0.09^{\mathrm{a}}$ & $1.52 \pm 0.09^{\mathrm{a}}$ & $1.17 \pm 0.07^{\mathrm{a}}$ \\
$\begin{array}{l}\text { Thymoquinone } \\
\begin{array}{l}\text { Nicotine and } \\
\text { thymoquinone }\end{array}\end{array}$ & $31.24 \pm 1.12^{\mathrm{c}}$ & $4.73 \pm 0.20^{\mathrm{c}}$ & $5.21 \pm 0.26^{\mathrm{c}}$ & $7.06 \pm 0.36^{\mathrm{c}}$ \\
\hline
\end{tabular}

${ }^{a b c}$ Subscripts within the same column show a significant difference $(p<0.05) ; n=8$ rats per control and treatment groups

\section{Gene expression of $P T 1$ and Tnp2}

The expression of PT1 was unaffected by nicotine and $\mathrm{TQ}$ as there was no significant change between the treatment groups and the control group (Figure 1). The Tnp2 gene showed no expression change in the TQ group but was significantly downregulated in the nicotine group $(0.047 \pm 0.009)$. However, the expression of Tnp2 in the nicotine-TQ group demonstrated a significant improvement compared to the nicotine group $(0.111 \pm 0.021)$ (Figure 2$)$.

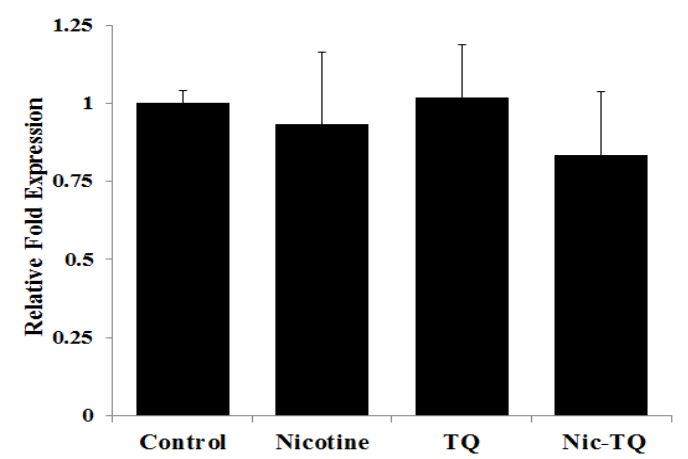

Figure 1: The effects of nicotine and thymoquinone on the expression of Protamine 1 (PT1). Results are expressed as normalized relative fold expression \pm SE

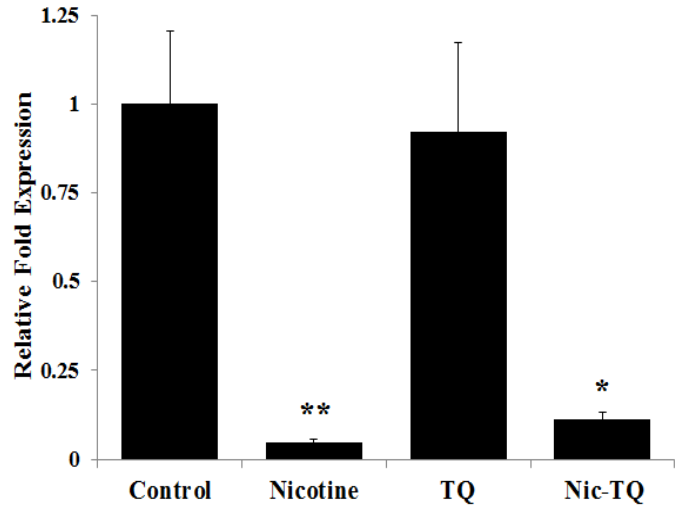

Figure 2: The effects of nicotine and thymoquinone on the expression of Tnp2. Results are expressed as normalized relative fold expression \pm SE. * Significantly different compared to the control group ( $p<0.05$ ). **Significantly different compared to control and nicotine-TQ group $(p<0.05)$

\section{DISCUSSION}

Nicotine is a toxic substance which can be rapidly absorbed through the respiratory system, skin and oral mucosa. It is responsible for various health problems including the alteration of sperm characteristics [14]. 
In this study, a quantified assessment of sperm DNA damage was carried out using the Comet assay. The nicotine group showed the highest amount of DNA breakage in all parameters compared to the other groups. This concurred with a study by Arabi [15] which showed that nicotine promotes significant membrane impairments and DNA fragmentations in sperm. The damage of DNA may arise from three main mechanisms: Abnormal chromatin packaging, apoptosis and oxidative stress. Nicotine has been well documented to cause oxidative stress and oxidative damage to sperm DNA, rendering it to lose its ability to fertilize the oocyte. Reactive oxygen species might harm DNA by directly attacking the bases and the deoxyribose backbone. It also induces apoptosis through caspases activation by the release of cytochrome C protein from disrupted mitochondrial membranes [16]. This eventually causes DNA breakage.

In addition, the present study demonstrated significantly less DNA fragmentation in the nicotine-TQ group in all DNA damage profile compared to the nicotine group. This shows that TQ treatment reduced the deleterious effects of nicotine on DNA integrity. This is in agreement with a previous report which showed that $T Q$ treatment caused a significant decrease in DNA damage in the cyclophosphamide-treated group [17]. The favorable effects of TQ could be implicated by its marked antioxidant capacity. Several studies have described TQ as an efficient scavenger of superoxide, hydroxyl radical and singlet molecular oxygen. The potent antioxidant potentials of $\mathrm{TQ}$ could reduce direct attacks of free radicals on the DNA molecule and mitochondria, thus reducing DNA fragmentation.

Apart from that, the expression levels of $P T 1$ and Tnp2 genes between groups were determined. The product of those genes, PT1 and Tnp2 proteins are important for condensed chromatin packaging. Inefficient chromatin remodeling increases the susceptibility of sperm DNA to damages from stressors such as free radicals. In this study, there were no changes in PT1 levels in all experimental groups compared to the control, indicating that nicotine and TQ have no influence on this particular gene. There was no prior study on the effects of nicotine on the protamination of sperm DNA. However, the result is in contrast to earlier findings whereby smoking was found to interfere with protamine expression at the mRNA level and these abnormalities could be attributed to smoking-related ROS [18].

The results of the current study further contradicted a study by Hammadeh et al who revealed that oxidative stress induced by cigarette smoking causes poor protamine replacement process [19]. The researchers also revealed that smoking affected PT1/Protamine 2 (PT2) expression ratio by the under-expression of PT2, suggesting that smoking affects PT2 greater than PT1. The genetic mechanism underlying smoking-induced protamine abnormality is still unclear.

Only PT1 was examined in the analysis of protamine expression in this current study given that rats, the model animal for the present study, do not express $P T 2$ [20]. It is unclear whether the unaltered expression of $P T 1$ in the current study was due to insubstantial nicotine inducement or nicotine having no effect on PT1. Consequently, the ameliorative role of TQ on PT1 gene was not able to be determined. Nevertheless, it can be safely assumed that the DNA damage observed in this study was not a result of abnormal PT1 expression.

Interestingly, Tnp2 was significantly downregulated in the nicotine group and showed improvements in the nicotine-TQ group. To the best of found knowledge, the effects of nicotine on Tnp2 expression level have not been studied, much less by TQ. Transition nuclear proteins (Tnp) participate in the initial condensation of the chromatin, where it transiently replaces the testis-specific histone variants before being replaced by protamines. This suggests that the disruption in Tnp expression may also impair DNA integrity. Some studies reported distinct roles for Tnp1 and Tnp2 proteins and proposed that Tnp1 is involved in histone removal whereas Tnp2 is involved in chromatin condensation [21]. Transition nuclear protein 2 (Tnp2) also affects DNA integrity through its roles in DNA nick repair during spermiogenesis and the ultimate degree of chromatin condensation [22]. Temporary nicks during histone-protamine replacement need to be fixed before they persist and evolve into DNA fragmentation in mature sperms.

The molecular mechanism responsible for nicotine-induced Tnp2 abnormality is still unclear. From the present study, it is possible to deduce that the alteration of Tnp2 expression level in the nicotine group may be caused by oxidative stress through the attack of ROS towards the mRNAs. As an antioxidant agent, TQ shows the ability to slightly improve Tnp2 expression in the nicotineTQ group. Hormone inhibition by nicotine might also provide a possible explanation for Tnp2 dysregulation.

Reports have indicated that nicotine could inhibit follicular stimulating hormone (FSH) and 
luteinizing hormone (LH) release from the pituitary gland. The inhibition of these hormones could affect Tnp2 regulation as deprivation of FSH signaling was found to greatly decrease Tnp and protamine levels [23]. Furthermore, Cacciola et al found that downregulation of $\mathrm{GnRH}$ occurred with Tnp2 mRNA [24]. However, there is no conclusive evidence of Tnp2 being involved in the direct pathway of the hypothalamicpituitary-testicular axis.

Nevertheless, it appears that the relationship between Tnp2 expression and DNA damage in this study has yet to be ascertained. A review paper by Leduc et al reported that DNA fragmentation in double Tnp knockout models did not persist and the DNA condensing impairment might be compensated by protamines [25]. Therefore, further investigation of the effect of nicotine and TQ on Tnp2 should be explored in the future.

\section{CONCLUSION}

The findings of this study show that administration of nicotine has harmful effects on sperm DNA quality and integrity in rats. However, administration of $\mathrm{TQ}$ improves the integrity of sperm DNA. Apart from that, in the analysis of genes responsible for sperm chromatin condensation, nicotine and TQ treatment demonstrated no effect on PT1 gene. This suggests that $P T 1$ gene does not influence sperm DNA damage in this study. Conversely, Tnp2 was signifycantly down-regulated in the nicotine group and showed improvement in nicotine-TQ group. Dysregulation of Tnp2 may have affected condensation and caused fragmentation of the DNA. Nevertheless, further studies are required to confirm these findings and to explore the effects of nicotine and TQ at the molecular level.

\section{DECLARATIONS}

\section{Acknowledgement}

The project was funded by University Malaya Research Grant (no. UMRG-RG378/15AFR). Immense gratitude to the Faculty of Medicine,
National University of Malaysia, for technical support and usage of facilities. Also, special thanks to Rafeah Pakri Mohamed for technical guidance.

\section{Conflict of interest}

No conflict of interest is associated with this work.

\section{Contribution of authors}

The authors declare that this work was done by the authors named in this article and all liabilities pertaining to claims relating to the content of this article will be borne by them. FDR was involved in carrying out the lab work, interpretation of data and preparation of the manuscript. $\mathrm{NHH}$ was involved in the grant application, study design and conduction, data analyses and manuscript revision. YMY designed experiment and participated in gene expression analysis. $\mathrm{KO}$ and SFI participated in the study design, and provided theoretical and technical guidance. NK was involved in study design and writing of the manuscript. All authors read and approved the final manuscript for publication.

\section{Open Access}

This is an Open Access article that uses a funding model which does not charge readers or their institutions for access and distributed under the terms of the Creative Commons Attribution License (http://creativecommons.org/licenses/by/ 4.0) and the Budapest Open Access Initiative (http://www.budapestopenaccessinitiative.org/rea d), which permit unrestricted use, distribution, and reproduction in any medium, provided the original work is properly credited.

\section{REFERENCES}

1. Ali Jorsaraei SG, Shibahara H, Ayustawati, Hirano $Y$, Shiraishi $Y$, Ali Khalatbari, Pasha $Y Y$, Suzuki M. The invitro effects of nicotine, cotinine and leptin on sperm parameters analyzed by CASA system. Int $J$ Reprod Biomed 2008; 6: 157-165.

2. Colagar $A H$, Jorsaraee GA, Marzony ET. Cigarette smoking and the risk of male infertility. Pak $J$ Biol Sci 2007; 10: 3870-3874.

3. Kavitharaj NK, Vijayammal $P$. Nicotine administration induced changes in the gonadal functions in male rats. Pharmacol 1999; 58: 2-7.

4. Mosadegh M, Hasanzadeh S, Razi M. Nicotine-induced damages in testicular tissue of rats; evidences for bcl-2, p53 and caspase-3 expression. Iran J Basic Med Sci 2017; 20(2): 199-208 
5. Silva PFN, Gadella BM. Detection of damage in mammalian sperm cells. Theriogenology 2006; 65: 958978.

6. Oliva R. Protamines and male infertility. Hum Reprod Update 2006; 12: 417-435.

7. Carrell DT, Emery BR, Hammoud S. Altered protamine expression and diminished spermatogenesis: what is the link? Hum Reprod Update 2007; 13: 313-327.

8. Darakhshan S, Pour AB, Colagar AH, Sisakhtnezhad S. Thymoquinone and its therapeutic potentials. Pharmacol Res 2015; 95: 138-158.

9. Hannan A, Saleem S, Chaudhary S, Barkaat M, Arshad MU. Anti-bacterial activity of Nigella sativa against clinical isolates of methicillin resistant Staphylococcus aureus. J Ayub Med Coll Abbottabad 2008; 20: 72-74.

10. Sayeed MSB, Shams T, Hossain SF, Rahman MR, Mostofa AGM, Kadir MF, Mahmood S, Asaduzzaman M. Nigella sativa $L$. seeds modulate mood, anxiety and cognition in healthy adolescent males. $J$ Ethnopharmacol 2014; 152: 156-162.

11. AlZahrani S, Mohany M, Kandeal S, Badr G. Thymoquinone and vitamin $E$ supplementation improve the reproductive characteristics of heat stressed male mice. J Med Plants Res 2012; 6: 493-499.

12. National Research Council, Guide for the Care and Use of Laboratory Animals. 8th ed. National Academies Press; 2011. p. 1-220.

13. Jamaludin N, Razak SSA, Jaffar FHF, Osman K, Ibrahim $S F$. The effect of smartphone's radiation frequency and exposure duration on NADPH oxidase 5 (NOX5) level in sperm parameters. Sains Malays 2017; 46: 1597-1602

14. Brčić Karačonji I. Facts about nicotine toxicity. Arh Hig Rada Toksikol 2005; 56: 363-371.

15. Arabi M. Nicotinic infertility: assessing DNA and plasma membrane integrity of human spermatozoa. Andrologia. 2004; 36: 305-310.

16. Wang X, Sharma RK, Sikka SC, Thomas AJ, Falcone T, Agarwal A. Oxidative stress is associated with increased apoptosis leading to spermatozoa DNA damage in patients with male factor infertility. Fertil Steril 2003; 80: 531-535.

17. Kamarzaman $S$, Sha'ban $M$, Rahman $S A$, Rahman $S A$. Effects on mouse spermatogenesis and DNA fragmentation following exposure to cyclophosphamide and thymoquinone. Euro Int J Sci Tech 2013; 2: 119136.

18. Yu B, Qi Y, Liu D, Gao X, Chen H, Bai C, Huang $Z$. Cigarette smoking is associated with abnormal histoneto-protamine transition in human sperm. Fertil Steril 2014; 101: 51-57.

19. Hammadeh ME, Hamad MF, Montenarh $M$, FischerHammadeh C. Protamine contents and P1/P2 ratio in human spermatozoa from smokers and nonsmokers. Hum Reprod 2010; 25: 2708-2720.

20. Bunick D, Balhorn R, Stanker LH, Hecht NB. Expression of the rat protamine 2 gene is suppressed at the level of transcription and translation. Exp Cell Res 1990; 188: 147-152.

21. Zhao M, Shirley CR, Yu YE, Mohapatra B, Zhang Y, Unni E, Deng JM, Arango NA, Terry NH, Weil MM, et al . Targeted disruption of the transition protein 2 gene affects sperm chromatin structure and reduces fertility in mice. Mol Cell Biol 2001; 21: 7243-7255.

22. Kierszenbaum AL. Transition nuclear proteins during spermiogenesis: unrepaired DNA breaks not allowed. Mol Reprod Dev 2001: 58: 357-358.

23. Blake CA. Paradoxical effects of drugs acting on the central nervous system on the preovulatory release of pituitary luteinizing hormone in pro-oestrous rats. J Endocrin 1978: 79: 319-326.

24. Cacciola G, Chioccarelli T, Fasano S, Pierantoni R, Cobellis $G$. Estrogens and spermiogenesis: new insights from type 1 cannabinoid receptor knockout mice. Int J Endocrin 2013: 501350.

25. Leduc F, Nkoma GB, Boissonneault G. Spermiogenesis and DNA repair: a possible etiology of human infertility and genetic disorders. Syst Biol Reprod Med 2008; 54 : 3-10. 